\title{
Neo-industrialization models and industrial culture of small towns
}

\author{
Tomaž Pipan ${ }^{1, \otimes}$ \\ ${ }^{1}$ Department of Landscape Architecture, Biotechnical Faculty, University of Ljubljana Jamnikarjeva ulica 101, 1000 Ljubljana, \\ Slovenia \\ ${ }^{\otimes}$ tomaz.pipan@bf.uni-lj.si
}

\begin{abstract}
In the last 30 years the global supply chains and containerization transformed the world of production and stretched it across the globe. With the exodus of Process and Assembly (P\&A) segment of industrial production from the developed countries, the "global north" not only lost the production capacity itself, but more importantly, the know-how in making that is a basis of industrial culture.

The neoliberal attitudes in industrial production were the main force behind slow but persistent abandonment of the automotive industry in Detroit, or closing down of the coal and iron industry in the Ruhr region in Germany. Contemporary urban renewal strategies of industrial areas rely on injection of tourism based on design, popular art, cultural and leisure activities, like the Emscher Landschaftspark in Ruhr region, Germany. However, tourism-based redevelopment is economically questionable in small industrial towns. For such areas we need to envision alternative agencies that industrial past and industrial production can offer. One of the most underrated aspects of industrial production is the know-how imbedded in the P\&A segment of industrial process. We argue for the industrial production know-how as a relevant part of the new innovation economy of small towns and of the local culture. This paper will trace the capacity of industrial production for culture-making by referring to production-innovation models described in regional geography. Firstly the paper identifies the P\&A know-how worth reshoring. Secondly, it describes two models of neo-industrialization in order to thirdly identify a new hybrid type of a regional model and its culture.
\end{abstract}

Keywords

Neo industrialization models,

Industrial culture,

Reshoring,

Small towns

Received:

27 March 2018

Received in revised form: 13 June 2018

Accepted:

15 June 2018

\section{Highlights for public administration, management and planning:}

- With the globalization of industrial production "global north" not only lost the production capacity itself, but more importantly, the know-how in making that is a basis of industrial culture.

- This paper puts forward the know-how in the P\&A segment of industrial production as a relevant part of new innovation economy for small towns and of local culture.

\section{Introduction}

From the 1920s to beginning of the 1970s, a territorial industrial model of mass production was established, based on ideas defined through the managerial and organizational change put forth by Frederick Winslow Taylor as "Scientific Management" (1919). The concepts of Taylorism were favouring a scientific look at each process of production in order to make it more streamlined, efficient and productive. Alongside Taylorism, modularization and segmentation of the production process pioneered in the Highland Plant in Detroit by Henry Ford gave rise to the modern assembly line
(Quivik 2003). These two breakthroughs are the basis of the modernist industrial process and modern spatial structuring of the territory. They profoundly transformed the industrial production process on one hand and gave birth to the industrial city of the 20th century on the other.

Taylorism and Fordism were boosting production and generated efficiencies that spawned a new middle class. A working class that, for the first time in the history, could live the "good life" and enjoyed the fruits of their labour. Cars, televisions, refrigerators, vacuum cleaners were all part of this new culture, something that is taken for granted nowadays. The new lifestyle was supported through the Keynesian economic system of stimulating demand giving 
the basis for the contemporary consumer culture. Keynes argued that the newly formed social order needs to be governed by a socially minded state that issues limits to capital exploitation and takes care of the welfare of the workers (Keynes 1936). The onset of neo-liberal ideas in the 1970s and 1980s went hand in hand with changes in industrial production, society and culture, creating a post-fordist society in the west where higher valued tertiary sector products (management, innovation and patents) increasingly replace the secondary sector (industrial production). The ambitions of industrial shareholders for economic gains fuelled production efficiencies and technological innovations that radically changed the established industrial city and drastically diverged from the Keynesian model. Three processes crucially supported the neo-liberal model of the industrial production; automation, cheap global transport, and atomization of the production processes. Industry was changing, from big regional producers, rooted locality to global multinationals binding individual industrial segments into global networks, organizing the workflow through global supply chains by implementing concepts such as "flexible specialisation" and "just in time production".

One of the major consequences of neo-liberal industrial process was atomization and global displacement of the low-wage process and assembly (P\&A) work from the developed countries (global north) to the developing countries (global south) where the labour was cheaper. The so-called offshoring was a de-facto strategy of the past 30 years, cutting costs by shedding the low-wage segments of production and focusing on the higher value segments (management and patents) for the sake of shortterm profits (Bailey \& De Propis 2014).

The neo-liberal network of production was in part possible due to unregulated industrial markets by the national institutions, lacking a long-term strategic vision of local sustainability. One of good examples is the fall of the textile protectionism in Europe when the Multi-Fibre Agreement (1974 to 2006) was dropped. This supported a sharp decline of textile industry in places like the north Italy (Hadjimichalis 2006:86) or the Twente region in the Netherlands (Beneworth \& Hospers 2007). The "race to the bottom" practice turned into a "herd mentality" where producers stopped thinking about any other repercussions (Fishmann 2012).It had no consideration for long-term consequences in terms of local economy or knowledge lost by abandoning the P\&A in Europe. To this effect, academics are proposing that the current re-shoring efforts are merely a balancing-out of race to the bottom (Bailey \& De Propris 2014).
One of the most affected territories were the small industrial towns all over Europe, where one type of industrial production would represent a major segment of the local economy (for example Jesenice or Tržič towns in Slovenia based on steel foundry or textile and shoe production respectfully). If central and regional centres always had healthy tertiary sectors to build upon after the industrial abandonment, the small industrial towns were not able to replace the loss of production economy. The faith of such towns at best was restructuring into suburban "satellite towns" of the regional centres, or, more frequently, going into economic and cultural decline with no prospect for the young generation. It is obvious that small towns in Europe will never be able to compete with regional centres in terms of tertiary economic segments. Therefore, this article looks again at the secondary (industrial production) sector and the P\&A segment to answer the following:

- What kind of model supports industrial production in small European towns?

- What kind of local culture such model requires?

\section{Methodology}

This paper is of qualitative rather than quantitative nature.It is contributing to the understanding of local topographies and their culture where global networks and processes of production are situated. Therefore, we will not raise all of descriptions to the level of concepts to be measured, but rather examine them in terms of concrete local conditions. This approach is chosen in order to reveal the correlations between cultural and processual economic spheres of the studied examples. The description of models is supported by the relevant bibliography in urban geography, economy and philosophy, on the subject.

To that effect, the paper is set up as a narrative comparison of models in order to reveal possible solutions for small towns.It will describe two neoindustrialization models in Europe: the Twente region in Netherlands (Beneworth \& Hospers 2007; Komninos 2002) and "Third Italy" - northeast area of Italy (Bagnasco 1977; Piore \& Sabel 1984; Hadjimichalis 2006). Evaluation is done as follows. Firstly, we identify the industrial production segment worth re-developing in small towns (Zirpoli \& Becker 2011a; Zirpoli \& Becker 2011b; Bettiol \& Micelli 2014; Bailey \& Depropis 2014). Secondly, we analyse above two production models in terms 
of (1) what kind of culture they create and (2) how feasible they are for implementation in small towns. Thirdly, as a contribution to knowledge, we suggest a hybrid model of production and describe its culture traits that fit small European towns in the contemporary global economy.

\section{Re-shoring industry and its culture}

\subsection{Re-shoring}

With the possibility of migrating the P\&A segments of the industrial production to the areas with a cheaper labour force, the global north sheds itself of physical production in the cities, but more crucially in Europe, deprives the small towns of a key economic segment. The traditional compact cities go into sharp decline and becomes just one of the poles within the global network structure (Sieverts 2003). The international mesh of flows and management turns territory into a field of agents, bound together by networks that are loosely connected, but based purely on the flow of information and the logic of free capital association and economics where the only value is the monetary return to the stakeholders. "The knowledge capitalism has become a mantra. Its gurus predict the weightless economy based on intangible goods and informatics" (Amin \&Thrift 2002:58).

The offshoring of the P\&A process cannot only be measured in the job loss. Increasingly, the voices of New Regionalism are suggesting that the main problem of the offshoring is the loss of competences, skills and learning-by-doing practices (Zirpoli \& Becker 2011a; Bettiol \& Micelli 2014). Whit the loss of material knowledge, we also lose a crucial capability for an "integrated product" (Zirpoli \& Becker 2011b) where research and development (R\&D) engineers and process and assembly (P\&A) skilled workers work side by side informing each other and developing the product, making it competitive (Fishmann 2012). Machine is incapable of adaptation whereas a skilled worker knows how to make things in many different ways under many different conditions because of his material knowledge, experience and know-how (Sennett 2008). Material knowledge is a critical part of the production process that the global north lost and needs to regain in order to provide the integrated product. A material knowledge in P\&A is paramount to make the final product delivering the integrated efficiencies in either cost, performance or quality (Zirpoli \& Becker 2011a; GE Appliances).
Not all of the P\&A processes will we ever be able to re-shore (Bailey \& Depropis 2014:385). Zirpoli and Becker studying the production process of a distinguished unnamed European car producer suggest two key segments where offshoring should never had happened and where key producers should do everything to retain the production process locally. "(1) things that have a direct impact on key product performance and (2) things that have a high degree of reciprocal interdependency with technologies that help determine overall product performance" (2011a:63). In other words, two key segments that contribute to competitive advantage are (1) specific technological knowledge needed to make the product and (2) innovative implementation of this knowledge to create an integrated product.

The integrated approach can be identified as a cornerstone of contemporary innovation where all other efficiencies in segmentation of production were already exhausted in the neo-liberal offshoring phase. Furthermore, the main identified segment of the integrated production process that is critically lacking due to these offshoring practices, is the material and making knowledge of the P\&A segment. As the main advantage of small towns in Europe is in their history of the industrial making knowledge, it is by working upon these foundations that will help to revitalize their local economy.

\subsection{Industry and culture}

The most common renewal of industry-deprived cities is through the injection of "artificial culture", whereas the culture is taken as an economic resource based on commercialization of the industrial past (Hospers 2002). This approach looks at industry and its knowledge as something to preserve, conserve, and exhibit, rather than as something to use proactively and innovatively for new industrial development and as part of the contemporary life.

There are two more limits to the "turistization" of industrial past. Firstly, research shows that touristic commodification of historical heritage will have hard time competing against the traditional touristic locations, such as warm seaside destinations that deal with relaxation as a favourite free time activity (Hudson in Amin \& Thrift 1995). This is even more so as the "new employment in industrial heritage tourism can never fully compensate for the loss of jobs resulting from the closure of the former work places" (Hospers 2002:401). Secondly, commodification of culture is a very competitive economic sector in Europe, as it is becoming one of the most widespread substitutes for other 
types of economic production. Example of the "European Cultural Capital" franchise is a case in point where regional cities like Wroclaw in 2016, or Riga in 2014 receive the title. Tourism is a heavily contested segment of economy where even the "Cultural Capital event is in itself not enough to guarantee success in the highly competitive European cultural tourism market, or to ensure structural improvements in the cultural climate." (Richards 2000:177).

From the perspective of the small European post-industrial towns, economy based on tourism is not a long-term solution, as it does not represent a sustainable project. Instead, it is far better to think of history of the industrial production through its know-how as a basis of local economy and cultural identity. Instead of drawing upon contemporary examples of "artificial culture" through tourism, an example from fordist era is more appropriate. Active industries in the fordist times were a source of personification of workers with the new city and its architecture. The rectilinear order of industrial estates was a source of civic pride and social, cultural and communal responsibility. This industrial culture was based on a reciprocal relationship with the fact that, for the first time in the history, the workers were able to buy the goods they were producing (Hoffman in Daskalakis 2001 eds.). In other words, a positive personification with the industrial making is possible in cultures where P\&A is still present and can support the workers to afford the goods of their own labour. This connection cannot be always confirmed for the post-fordist P\&A regions in the global south such as Dongguan, China. Dongguan in Peral River Delta is the main area of P\&A type of industrialization in China (Pipan 2014) and does not offer the fruits of its labour to its labourers.

From the cultural aspect, the viability of industrial production hinges on a possibility of a "good life" for the workers that is in itself a reciprocal relationship between production and personification with products generated. Only such attitude can help us retain production and enable the vision of smalltown culture based on local know-how in making and production.

\section{Discussion: neo-industrialization models}

Which neo-industrialization models exist that help regain the production in small European towns? In this section two models of industrialization will be evaluated against the two research topics - how feasible are the models for implementation in small towns and what kind of local culture each model requires. First model is the Twente region in Netherlands, dealing with introduction of applied innovations hub based on traditional knowledge of textiles. Second example takes as a starting point a networked condition of north Italy where the regional pattern of small producers is the source of the innovation.

\subsection{Neo-industrialization through knowledge economy}

The Twente region (Enschede, Hengelo, and Almelo cities) was famous for its textiles and weaving since the 19th century. Due to the offshoring cheaper Asian producers and loss of Dutch cotton colonies in the 1950s, the textile industry in the area went into sharp decline from the 1970s onwards. Regeneration efforst began from the industrial sector. Key industrialists started to promote creation of an entrepreneurial university Twente University (TU) through which local textile knowledge and knowhow (from making yarns, weaving to making the textile machines) can be retained and enriched. A new geographic organization of the Twente region was envisioned built on basis of the institutional hightech innovation. The idea was to combine the networks of existing producers, and global networks of the new professors in TU, in order to develop new high-tech products based on competitive research environment. After a 20 year process, the university plays a vital role in connecting and "patching up" the regional innovation ecology, giving it a boost through facilitation of research on one side and by providing the managerial and network infrastructure, through the incubators and accelerators, entrepreneurial schemes, knowledge circles and regional venture funds (ad lib. Beneworth \& Hospers 2007).

In this model, the traditional industrial segments of yarn making, weaving and textile machine making, were developed into high-tech research and industrial ventures. In this way the Chair for Production Technology at TU (clear connection to the knowledge of making yarns), MESA+ Institute for Nanotechnology (an applied research institute coming out of textile production industry) and Micro Machining Group (coming out of weaving machining knowledge) have been created ${ }^{1}$.

What kind of culture this model creates? The Twente region model creates a topography of competition based on innovation with a strong regional node.It represents a strategic project that needs a support of the regional government. The culture of innovation follows closely the science 
park concept. The economy based on knowledge started to develop as early as the 1950s in connection to the cold war industry and state funding in the US, when a high-tech research and knowledge driven research centre at Stanford Industrial Park in Palo Alto was opened. This was a precursor to what has become the Silicon Valley and was the deliberate creation of a place that "drew on technological breakthroughs achieved (often under military sponsorship) in university laboratories" (Piore \& Sabel 1984:286). This type of a model requires a culture that is adaptable and roots its definition in perpetual competition and reinvention. The only stable element and reference through which a kind of continuity is possible is oneself.

How feasible is the model for implementation in small towns? The Twente model needs a strong regional support. Komninos (2002:29) describes an array of services and external support needed for such an environment to succeed: from large industrial complexes to innovation support programmes, high-tech education, business services and venture capital funds. The model requires a strong financial backing and strategic (long-term) dedication, which is hard to envision in smaller towns. As there can only be one regional centre with a university where access to global markets are supported institutionally, it is less feasible that small towns can benefit from such models directly. In this model the knowledge and innovation is aggregated in one point, however for small town the main questions is how to retain knowledge and innovation in each individual node of the network. Only if we retain a dispersed innovation and only if this innovation is connected to making, can we achieve an (economically) sustainable development in small post-industrial European towns.

\subsection{Neo-industrialization through flexible- specialization}

The second example is coming out of the New Regionalism debate supporting a regional networked pattern of small producers, who can adapt to new conditions and find niche markets. Here the example of north Italy can be adduced, first defined by Bagnasco (1977) as Third Italy. Third Italy is a regionally bound economy based on small and flexible industrial production of local producers creating local clusters of excellence. According to Bagnasco there are three reasons for success of Third Italy. (1) Small firms filled in niche markets and specialized in small batch productions, (2) they were catering for non-mass produced segments (jewellery, silk industry, tanning, marble quarrying, etc.) and (3) a bad socio-political position of workers in the 1960s
Italy resulted in workers starting their own small businesses. Third Italy argues for a contemporary urban culture based not only on tertiary sectors, but also on "many specialized agglomerations of artisanal firms producing design-intensive product" (Scott 1988:180) drawing its continuity from the craft society. This type of industrial production was first theorized by Marshall in 1890, who spoke of clusters of industries and in favour of economic and social resiliency of these clusters if "several distinct industries are strongly developed." (Marshall 1890:170) The Third Italy retained an advantage over mass production through specialisation, skill retention and modernisation, becoming an "alternative to mass production as a model of technological advance." (Piore \& Sabel 1984:28).

What kind of culture this model creates? Third Italy was especially praised due to the varied production - textiles, precision machine tools, food, gold working, wood and furniture, processing of minerals, ceramics, etc. (Italian Institute for Foreign Trade 1989:229-234). All this variety existed within local networks of artisans and producers, to a large extent privately owned by individual families. This filial tradition and continuity shows a different basis for the organization of social and civic participation then the competitive innovation model in Twente. Piore and Sabel discuss the similarity of ethical norms between similar producers, due to affiliation and belonging where "a breach of the standard violates not only an economic contract, but also deeply held community mores." (Piore \& Sabel 1984:266) This model offers a way to rethink local culture based on making and production, where value of production is retained through the family values and personification. Production retains its cultural value as it offers a viable future.

How feasible is the model for implementation in small towns? The fact is that even if the local clusters of Third Italy supported a rich local metabolism it was impossible to escape the competition of the global market where "de-localization breaks down local clusters and networks and builds up new hierarchies resembling many characteristics of vertically integrated multilocational companies." (Hadjimichalis 2006:102) Hadjimichalis argues that Third Italy is not a viable model for sustainable, small-scale, family-run, flexible industries supporting a local community because the global labour market and price relations are interconnected and make such environment economically unsustainable on the global stage. "Made in Italy" carries a certain level of authority, but quality and design matter only to a certain extent in the capitalist market. In addition, global brand names like Prada still control the market and delegate prices 
to their subcontractors where Third Italy firms cannot compete. Third Italy would also not be able to exist without strong economic and policy support of the state, like the Multi Fibre Agreement Act by the EU that safeguards local producers states Handjimichalis. However, the grain and dispersion of Third Italy is ideal for small towns, as is the filial organization that fosters local entrepreneurship and innovation.

\section{Conclusion: A hybrid model for small towns}

\subsection{What kind of industrial culture can we en- vision in small post-industrial towns, and how to achieve it?}

This article looked at the consequences of offshoring for small industrial towns in Europe. Due to the loss of secondary economic sector (industrial production), these towns went into a sharp decline over the last 30 years in a process of deindustrialization. The central and regional cities were able to restructure based on tertiary sectors such as services, innovation and cultural tourism - finding new economic markets. Small towns could not compete against these centres and had hard time adapting their economy to tourism or services as their economic base. An alternative for small European towns is needed. One of such is re-shoring parts of the P\&A process. The most promising segment of the P\&A to re-shore are practices that affect quality of innovation. That is, the technological knowledge and how this knowledge is used to create an integrated product. Only production that integrates the R\&D and the P\&A segments in the innovation phase can expect efficiencies in either cost, performance or quality. Due to the offshoring, the knowledge imbedded in the P\&A is chronically lacking in the west. That is the knowledge that still exists in small towns where industrial production was the main economic sector and source of local identity.

\subsection{How to retain industrial production in small towns?}

The Twente model shows the transformation of industrial production to knowledge economy.It shows redevelopment of industry intensive textile region through an innovation environment based around a new university. This model is hard to implement in small towns as it firstly supports the dominancy of one regional place over the periphery and sec- ondly replaces the material know-how with research innovation. However, the positive part of this model is the entrepreneurial spirit it fosters within the local innovation network - creating an innovative entrepreneurial culture. This can be a basis for any local culture supporting innovative production.

The Third Italy model shows a continuation of production in the west through flexible specialisation based on small industrial production, retaining production knowledge and innovation in making. Spatially it is reproduced through local clusters of excellence based on professional network and is based on small traditional, family led production. Here culture of local identity, family and professional affiliation play important roles for the local economy. However, this model went into decline in the 1980s due to the loss of policy protectionism and P\&A offshoring of global producers to the global south. A hybrid model between the Third Italy and the Twente models that combines the virtues of both can be envisioned that supports new type of economy in small European towns. Such restructuring is happening in the north Italy (Chiarvesio et al. 2010). Here the global connections and local networks of producers are retained through one major local producer who is economically and ethically connected to the local network of producers on one side and to the global market and offshoring regions on the other. Its offshoring is used in conjunction with the local innovation-led production, bringing benefits also to the lower tier producers.

This type of organization also needs a significant change of the local network of small producers. If before it was based on craft and niche production of final products, now the artisan and craft knowledge is used to develop high-tech innovation in production process and the production technology. This re-contextualisation of local network is needed to develop innovative products jointly with the medium-sized industrial company, linking the R\&D and the P\&A to deliver innovation in process as well as product development (Micelli \& Saccehetti 2014). In this model, we see innovation fostered locally by the individual small producers rather than centrally in the university environment as is the example in the Twente model

\subsection{What kind of local culture such model re- quires?}

In this model, we see innovation through production fostered locally in individual small producers under the "patronage" of a local medium-sized industrial company. In order to support such hybrid model there are a few cultural predispositions needed. (1) Emphasis of the place needs to be put 
on "the culture of making" - the local environment needs to value applied knowledge and make it part of its identity. This is a long-term process but is achievable through local organizations that support networks of producers, education in schools and support of high schools in applied sectors. (2) The culture of making is not sustainable without the entrepreneurial and innovation spirit. Values of how to take risks, how to develop new solutions through making needs to be fostered. (3) In order to disperse the innovation-making one of the best examples is a topography where making is part of everyday culture, for example the Third Italy example where this is achieved through family owned industries. (4) The local small producers will only prosper through favourable regional policies and regional support. Investment into production knowledge is a national investment as is education in universities. Both should be valued equally which is currently not the case. (5) Such model is only achievable when a medium-sized industrial company realises its success is dependent upon its local ethics and long-term engagement and that it is only one of the nodes within the global network where small innovative producers also play a vital role. Idea to redevelop small European towns based on industrial culture is well established; however, it mainly revolves around touristization of that culture. To base economy on tourism of industrial past is not feasible for long-term development of small towns if they want to grow and sustain themselves.It is far better to understand the local production knowledge as operative element of local development strategies. The retention of production know-how suggests a new direction for understanding of the industrial culture in post-fordist global north.

\section{Notes}

\footnotetext{
${ }^{1}$ Information obtained by the author through aggregated online searches, looking at the departments and organization of Twente University and following up on their spinoffs and affiliated industries, reading on the main segments of development of these firms.
}

\section{References}

Amin A, Thrift N (2002) Cities: reimagining the urban. Polity, Cambridge, UK.

Bagnasco A (1977) Tre Italia. Problematiche dello sviluppo italiano. La problematica territoriale delle sviluppo italiano.

Bailey D, De Propris L (2014) Manufacturing reshoring and its limits: the UK automotive case. Cambridge Journal of Regions, Economy \& Society 7: 379-395.

Benneworth P, Hospers G-J (2007) The New Economic Geography of Old Industrial Regions: Universities as Global - Local Pipelines. Environ Planning C Government Policy 25: 779-802.

Bettiol M, Micelli S (2014) The Hidden Side of Design: The Relevance of Artisanship. Design Issues 30: 7-18.

Daskalakis G, Waldheim C, Young J (2001 eds.) Stalking Detroit. Actar, Barcelona.

Fishman C (2012) The Insourcing Boom. The Atlantic.

GE Appliances, n.d. The Skinny on Lean: UseIt or LoseIt - GE Appliances and the Lean Process [WWW Document]. GE Appliances Pressroom. URL http://pressroom.geappliances.com/facts/theskinny-on-lean-230762 (accessed 9.29.16).

Hadjimichalis C (2006) The End of Third Italy As We Knew It? Antipode 38: 82-106.

Hospers G-J (2002) Industrial Heritage Tourism and Regional Restructuring in the European Union. European Planning Studies 10: 397-404.

Italian Institute for Foreign Trade (1989) Italy: the unique role of its local economies. Italian Institute for Foreign Trade, Rome, Italy.

Keynes JM (1936) The General theory of employment interest and money. Macmillan, London, UK.

Komninos N (2002) Intelligent cities: innovation, knowledge systems, and digital spaces. Spon Press, London, New York.

Micelli S, Sacchetti V (2014) Made in Italy: A Decade of Change. The Journal of Modern Craft 7: 81-88.

Piore MJ, Sabel CF (1984) The second industrial divide: possibilities for prosperity. Basic Books, New York.

Quivik FL (2002) Rosie the Riveter National Historical Park, Ford Assembly Plant (No. HAER CA-326-H). Historic American Engineering Record, Washington DC.

Richards G (2000) The European cultural capital event: Strategic weapon in the cultural arms race? International Journal of Cultural Policy 6: 159-181.

Sennett R (2008) The craftsman. Yale University Press, New Haven.

Sieverts T (2003) Cities Without Cities: An Interpretation of the Zwischenstadt. Routledge, London.

Taylor FW (1919) The principles of scientific management. Harper \& Brothers, New York, London.

Zirpoli F, Becker MC (2011a) What Happens When You Outsource Too Much? MIT Sloan Management Review.

Zirpoli F, Becker MC (2011b) The limits of design and engineering outsourcing: performance integration and the unfulfilled promises of modularity. R\&D Management 41: 21-43. 